\title{
3D Servicescape Model: Atmospheric Qualities of Virtual Reality Retailing
}

\author{
Aasim Munir Dad \\ The School of Business \& \\ Management \\ University of Gloucestershire \\ United Kingdom
}

\author{
Professor Barry Davies \\ The School of Business \& \\ Management \\ University of Gloucestershire \\ United Kingdom
}

\author{
Dr. Asma Abdul Rehman \\ Cardiff Metropolitan University \\ United Kingdom
}

\begin{abstract}
The purpose of this paper is to provide a 3D servicescape conceptual model which explores the potential effect of 3D virtual reality retail stores' environment on shoppers' behaviour. Extensive review of literature within two different domains, namely: servicescape models, and retail atmospherics, was carried out in order to propose a conceptual model. Further, eight detailed interviews were conducted to confirm the stimulus dimension of the conceptual model. A 3D servicescape conceptual model is offered on the basis of stimulus-organism-dimension, which proposes that a 3D virtual reality retail (VRR) store environment consists of physical, social, socially symbolic and natural dimensions. These dimensions are proposed to affect shoppers' behaviour through the mediating variables of emotions (pleasure and arousal). An interrelationship between pleasure and arousal, as mediating variables, is also proposed. This research opens a number of new avenues for further research through the proposed model of shoppers' behaviour in a VRR store environment. Further, a systematic taxonomy development of VRR store environment is attempted through this proposed model that may prove to be an important step in theory building. A comprehensive 3D service scape model along with a large number of propositions is made to define a 3D VRR store environment.
\end{abstract}

Keywords-Virtual Reality Retailing (VRR); Servicescape; 3D Servicescape; Retail Atmospherics; Shoppers' behaviour

\section{INTRODUCTION}

Consumer behaviour has been known to be one of the most important areas of interest for marketers and academics for a long time (Dooley et al., 2012; Richarme, 2007). Organizations are always interested to know the effect of almost every single marketing activity on customers' behaviour and the reason for this is they want to satisfy their customers' needs such that they keep making a profit in the market (Schiffman et al., 2010; Young et al., 2010). Within the realm of consumer behaviour, the most popular research is the one in which researchers investigates the effect of the retail environment on shoppers' positive or negative shopping behaviour (Graves, 2013).

Retailing is one of the oldest models of selling goods; however, today the face of retail industry has been changed a lot because of new technological developments within it (Chang, 2014). The internet has made shopping far quicker, easier and more efficient; today shoppers can shop using their mobile devices (e.g. cell phones, tablets etc.) and desktop computers while comparing prices and quality at the same time. Self-check and contactless payments made the shopping process faster (Gibbs, 2015; Chang, 2014).

In the past, shoppers had two main channels of retailing: brick and mortar and web retailing (present on web 2.0 interface). However, today shoppers have another newly emerging channel called $3 \mathrm{D}$ virtual reality retailing, which is accessible in 3D virtual worlds. These 3D VRR stores are present in 3D virtual worlds, where users (known as residents) can buy and sell goods by exchanging virtual money (Vrechopoulos et al., 2009). As mentioned here and in detail in the literature review, there is a plethora of research into brick and mortar and online retail environments; however, research into virtual reality retail environments is still in its infancy (Hassouneh and Brengman, 2015; Krasonikolakis et al., 2011).

The current study provides a parallel research in the context of 3D virtual reality retail stores environment. Some researchers (Hassouneh and Brengman, 2015; Krasonikolakis et al., 2011; Vrechopoulos et al., 2009) have already started calling for more systematic research on the nature of the 3D virtual reality retail format by using established retailing and consumer behaviour theories. A large number of research questions have emerged in the domain of retail atmospherics; considering the impact of brick and mortar and web retail atmospheres on shoppers' behaviour; this prompts such questions as: what, if any, is the role of such atmospheric cues in the 3D virtual reality retail (VRR) shopping environment? What cues do virtual shoppers notice while shopping in 3D VRR stores? What is the effect of 3D VRR stores' environmental cues on shoppers' emotions and behaviours, for instance pleasure, arousal, dominance, satisfaction, and approach or avoidance behaviours? The purpose of this study is to provide a basic 3D VRR store atmospherics domain. The objective of this research is to define the $3 \mathrm{D}$ virtual reality retail store environment by establishing a list of stimuli that form a 3D VRR store environment.

\section{LITERATURE REVIEW}

In this section, a brief review of literature is presented to understand the relationship between the retail environment and shoppers' behaviour. The aim of this research is to explore 3D virtual reality retail stores' environments and their effect on virtual shoppers' behaviour; however, there is a paucity of research in this new electronic channel of retailing. Therefore, parallel literature is reviewed in terms of brick and 
mortar and traditional online (2 dimensional/ 2D / Web 2.0) retailing. A model is also conceptualized on the basis of a theoretical review of brick and mortar and online retail environment studies.

\section{A. The Retail Environment and Shoppers' Behaviour:}

According to The Statistical Portal, in the UK in 2014, $£ 404.26$ billion was generated in the retail industry as sales revenue (Statista, 2015) and it is estimated to be $£ 443.25$ billion in 2018. Moreover, in the United States retail sales generated a record sales revenue of $\$ 4.5$ trillion in 2013, which is expected to rise to $\$ 5.552$ trillion in 2018 (eMarketer, 2014). The retail industry has grown enormously and today there is huge competition among retailers and there are about 281,930 retailers on the UK's high streets (Centre of Retail Research, 2013). Baker et al. (1992) postulated that since creating a competitive advantage through product differentiation in this era is almost impossible, retailers can create differentiation through the retail store itself. Solomon et al. (2006) supported Baker's statement by arguing that in today's world of huge competition, many retail stores and airlines also try to create differentiation with their competitors by providing a unique environment to their customers. Graves (2013) confirmed all the previous research and determined that if retailers want to know about why shoppers buy what they buy or why they do not, then retailers need to understand the chemistry of the retail environment and how it influences shoppers' behaviour. According to Quartier (2011), research in this area is called 'retailology'. Researchers have been discussing the retail environment and its effect on shoppers since 1973; Kotler (1973) was the first to discuss the retail atmosphere and declare it as an important part of the 'Total Product'. Kotler (1973) further categorized the environment into two parts: Intended Environment and Perceived Environment. Intended Environment is created by the retailers through planning, whereas the Perceived Environment is the one which is judged or perceived by the consumers, which varies from consumer to consumer because of their individual personality characteristics (Kotler, 1973).

Furthermore, customers obtain satisfaction from their shopping when the entire shopping experience either meets or exceeds their expectations prior to shopping, and it can be achieved when they have ease in shopping, ease in fulfilling the transaction process, and customer satisfaction after purchasing and consuming goods or services (Dunne et al., 2002). Furthermore, it has already been proven that the store environment (store layouts and design: one of the important environmental cues of the brick and mortar and online retail environment) plays an important role in providing shoppers with a feeling of ease in shopping (Manganari et al., 2011; Vrechopoulos et al., 2004). Other researchers have also provided a plethora of research in which they have proven that the retail environment contributes a major role for making shopping easy and enjoyable (Varley and Rafiq, 2014; Quartier, 2011; Dunne et al., 2002; Eroglu et al., 2001; Donovan et al., 1994; Donovan and Rossiter, 1982). Graves (2013) claimed that to maximise sales it is vital that the retail environment is optimised. Moreover, the environment and its effect on people has long been discussed in the field of psychology (for example, by Stokols, 1978; Mehrabian, 1976;
Craik, 1973) and Mehrabian and Russell (M-R, 1974) are credited with presenting a Stimulus - Organism - Response (S - O - R) model, which postulates that every environment affects the human beings present in it. This model further explains that every environment affects human emotions (Mehrabian and Russell posited that all types of human emotions could be categorised into three main emotions i.e. Pleasure, Arousal, and Dominance, also known as PAD), which lead individuals to show either approach or avoidance behaviour. This M-R model was later modified by Russell and Pratt (1980), who deleted the dominance dimension of the emotions because of its weak relationship with behaviour. Most retail environment studies (e.g. Wang et al., 2011; Davis et al., 2008; Baker et al., 1992; Donovan and Rossiter, 1982) that have adapted the M-R model did not include the dominance dimension, as suggested by Russell and Pratt (1980). In this research the dominance dimension is also not considered, as suggested by Russell and Pratt (1980). Their theory is general enough to be applicable in any kind of environment, even in a retail environment. However, environmental psychologists tended to focus on different environments (such as residential, entertainment, institutional, hospitals, schools and prisons) instead of retail environments before 1982 (Quartier, 2011; Donovan and Rossiter, 1982). Therefore, Donovan and Rossiter (1982) were pioneers in applying Mehrabian and Russell's S-O-R framework in the 'retail' context. This model of Mehrabian and Russell (1974) is discussed in detail later on in this study.

At this time a few studies on the retail environment and its effect on consumers' behaviour had been conducted, but the environment-behaviour relation was not conceptualized properly before Donovan and Rossiter's work in 1982. Though a few retailers had claimed that many environmental cues (e.g. layout and design etc.) affected consumers' shopping experience (Wysocki, 1979), their claim was not supported by any empirical evidence until the study of Donovan and Rossiter (1982). After the successful application of the Mehrabian and Russell (M-R) theory in the work of Donovan and Rossiter (1982), there were subsequently a number of studies in which researchers applied the M-R theory in the retail context (e.g. Hunter and Mukerji, 2011; Quartier, 2011; Kim and Lenon, 2010; Eroglu et al., 2003; Sherman et al., 1997; Donovan et al., 1994).

Since the development of conventional retail stores (Brick Environment), the retail atmosphere and its effect on shoppers has remained the primary interest of marketers and academic researchers (Turley and Milliman, 2000). Since 1982, as discussed above, researchers have done a lot in this area and explored many surprising effects of retail environments on shoppers' behaviour. Some of these researchers used a holistic approach to study the whole environment and its effect on shoppers (e.g. Donovan and Rossiter, 1982), while some others adopted a micro level approach to measure the effect of any/a few environmental cue(s), such as Music, Lighting and Colour, on different variables affecting consumer behaviour in the retail environment. For instance, Milliman (1982) measured the impact of music tempo on traffic pace, sales volume and music awareness; Bateson and Hui (1987) examined the effect of crowding on the approach/avoidance 
behaviour of shoppers; Lyer (1989) cited in Kalla and Arora, 2011) studied the relationship between a store's layout and impulse purchase behaviour of shoppers; Machleit et al. (1994) observed the relationship between crowding and consumer satisfaction; Reddy et al. (2011) studied the role of in-store lighting in contributing to consumer satisfaction.

The development in information technology is surprising; for example, Haeckel (1998) foresaw that these frequent developments in technology and the internet would definitely change the human cognition process. This development in technology made it possible for shoppers to purchase almost everything from their homes through the internet. The internet changed the concept of retailing, making online shopping possible and a simple process. Eroglu et al. (2001) said that online retail stores' environment (Click) affects the sequence of behaviours of shoppers through the webpage in the same way that a traditional retail store's environment (Brick) does. Eroglu et al. (2001) were pioneers who did research in the area of the online retail environment and later a huge number of researchers followed them and confirmed their propositions (Koo and Ju, 2010; Hunter and Mukerji, 2008; Chang and Chen, 2008; Wu et al., 2008; Price-Rankin, 2004; Eroglu et al., 2003). However, some of the environmental cues of a brick environment are not present in the click environment, e.g. olfactory cues. This development of web/online retail stores provided academic researchers and marketers with a wide field for new research (Manganari et al., 2009).

Although research on the impact of online retail stores' environments is not as old as that conducted for tradition retail stores, since it has only been practised for the past sixteen years; there is still a lot of empirical evidence showing that the environment of online retail stores has a significant impact on consumers' behaviour. Hunter and Mukerji (2011) argued that researchers applied a number of studies of brick environments into click environments and found that the online stores' environmental cues affect the shoppers' behaviour in the same way as the conventional stores' environmental cues do. Likewise, the M-R theory, which provides the S-O-R framework, has also been tested in many studies to prove the impact of an online store's environment on online shoppers. After the conventional stores studies, the M-R model has been applied successfully in a wide range of studies of online retail stores' environments (e.g. Manganari et al., 2011; Wu et al., 2008; Eroglu et al., 2003).

\section{B. The Background and History of Virtual Worlds:}

According to Nood and Attema (2006) the virtual world is not a novel concept as it was regarded in the past; in fact, they see it as old as "Dreaming". There have been two kinds of worlds from the beginning: a primary world and a secondary world (Auden, 1968). The primary world is the world in which a person can feel or see by using sensory organs, whilst the secondary world is the world of a person's imagination. As a species, Man always, consciously or unconsciously, imagines many things in his/her mind. Computerized virtual worlds (VWs) were initially played only as 3D video games. VWs are also known as Massively Multiplayer Online Games and different terms are used synonymously, e.g. Massively MultiPlayer Online Role Playing Games (MMORPGs), Multi-User Online Virtual Environments (MUVEs), and Networked
Virtual Environments (NVEs). Instead of using virtual worlds just for entertainment purposes, users are now using them for social interaction amongst one another in their daily routines (Wyld, 2010). The number of users of these worlds is increasing day by day and it seems that Gartner's (2007) prediction will become true that the number of VW users will reach one billion by 2018. According to DFC intelligence the world's gaming market was worth $\$ 67$ billion in 2012 and it is expected to grow to $\$ 82$ billion over the subsequent five years. In the past, video games were less interactive, single player oriented and users were of a young age. Nonetheless, now virtual worlds are highly interactive, multi-players can interact instantaneously and the users belong to groups of all ages (Adolph, 2011; ITU Telecommunication Standardization Bureau, 2011).

Today's virtual worlds are more developed, interactive and collaborative; therefore, there are many opportunities for different disciplines of life (Barnes and Mattsson, 2008). 3D virtual worlds are commonly categorized into two forms, game oriented and free form virtual worlds (Bainbridge, 2007). Game oriented virtual worlds, e.g. World of Warcraft, are only used for gaming purposes. Avatars (an electronic body to represent users in virtual worlds) are bound to wear some specific items to play within that environment. In game oriented virtual worlds users usually play with computercontrolled characters and try to win the levels of the game just for pleasure or entertainment. For this purpose users might have to purchase some virtual items to make them powerful in the game to win the level. The free form of virtual worlds (e.g. Second Life) are totally different in nature, as users are not there to play games but are free to perform most of their real life activities within the virtual world. Free form VWs are more similar to the real world; they are also known as open virtual worlds (Messinger et al., 2008). People buy and sell different kinds of applications, such as virtual apparels for their avatars, lands, islands, virtual vehicles and many more items. They can do many activities within these virtual worlds that are more simulative to the real world.

\section{Three Dimensional (3D) Retail Stores:}

Three dimensional (3D) retail stores, also called 3D virtual reality retail (VRR) stores, provide a new and innovative way of shopping, full of opportunities for both retailers and shoppers (Vrechopoulos et al., 2009). These 3D stores, or VRR stores, are available in 3D virtual worlds. Virtual reality retail stores have given a new concept to the retail industry. Virtual reality retail (VRR) stores are present within these 3D VWs, some of which offer virtual goods for free and some that are really costly. The virtual world has provided businesses with a new opportunity to market and sell their products. Virtual worlds (e.g. Second Life) are offering an alternative, improved, and quite potential medium to the consumers where they can shop for their virtual lives by paying with virtual money (e.g. Linden Dollars in Second Life). In the same way consumers can also buy for their real lives, but this is just at an introductory stage at the moment (Vrechopoulos et al., 2009).

Unlike web retail stores where many components of traditional retail environments are absent, e.g. Social Factor, the VRR stores that are made up of computer graphics that provide a real world simulated environment. VRR stores, like 
real world stores, are constructed with walls, colours, lighting, in-store music, floors, shelves, layout and design. One of the components of a retail store's environment is social presence, i.e. the presence of other customers or employees.

VWs are providing real world retailers with a unique opportunity to set up their retail business inside these virtual stores (Haenlein and Kaplan, 2009), but the concept of retailing in VWs is quite different to that of traditional web 2.0 technology. If traditional online stores are analysed, many discrepancies will be found; for instance, the images of products placed on traditional online stores are not true representations of the real product (Keeney, 1999). Moreover, whilst visiting traditional online stores there is a feeling of loneliness and inadequate interaction with other customers (Wang et al., 2007). This is not the case with VWs as they provide the customers with a simulated real environment. The retail stores are built within a 3D electronic environment where all the products are 3D electronic objects that closely resemble the real world product. Moreover, visitors of VRR stores can also interact with one another (Haenlein and Kaplan, 2009). Virtual reality retail stores are the most appropriate representation of real world stores, which could enhance a company's branding and advertising campaigns. It has also been proven through previous studies that 3D object placement in VWs has a very positive impact on users' intentions to purchase the same product in real life (Schlosser, 2006: 2003).

Kukreja and Humphreys (2014) argue that in traditional online stores, goods or services were shown on two dimensional flat interfaces where shoppers are not able to see a $3 \mathrm{D}$ view of the product. Moving inside traditional web stores is known as 'scrolling down or up'. Kukreja and Humphreys (2014) determined that 3D virtual reality retail stores are a substitute for $2 \mathrm{D}$ web stores. They are far better than web store and shoppers can move around the stores by walking, flying or running with the help of their avatars. There is none of the navigational difficulty in 3D VRR stores which shoppers face in traditional web retailing (Kukreja and Humphreys, 2014).

\section{Research in $3 D$ retail environment:}

As aforementioned, today's world has another retailing channel in the form of 3D virtual reality retail stores, which are present in VWs. Not only do retailers have more options to market their products now, shoppers have multichannels to shop in too. Therefore, all these available shopping mediums should be examined from a consumer's perspective (McGoldrick and Collins, 2007).

There is a surfeit of research on traditional and web retail environments and how they affect a varied range of consumers' emotions and behaviours. However, in the case of VRR environments the research is still in its infancy (Hassouneh and Brenjman, 2015; Krasonikolakis et al., 2011; Vrechopoulos et al., 2009). These VWs have existed since 2003 (Shen and Eder, 2009), but remain ignored by retail environment researchers in terms of parallel research in VRR environments to find out how this environment affects the behaviour of virtual shoppers. To date, there are only three known studies in the context of 3D VRR stores atmospherics
(Hassouneh and Brenjman, 2015; Krasonikolakis et al., 2011; Vrechopoulos et al., 2009); however, there is only one known research investigating the effect of the layout of 3D virtual reality retail stores on shoppers' behaviours, with a result that found no effect at all (Vrechopoulos et al., 2009). Vrechopoulos et al. (2009) opened the door for future exploration of VRR stores' environmental cues other than layout and design, such as crowding, sounds and store theatrics.

The objective of this research is to generate a list of stimuli which could be a part of 3D VRR store environments and affect shoppers' emotions and behaviour. There are two existing studies which made an attempt to generate a list of stimuli (Hassouneh and Brengman, 2015; Krasonikolakis et al., 2011). These two studies proved that there is a need to investigate the effect of 3D VRR store atmospherics on shoppers' behaviour. However, these studies defined the environment of 3D VRR stores but did not specify the different environmental cues. Moreover, Krasonikolakis et al. (2011) also did not mention the usage of these atmospherics in VRR stores. In this research a list of stimuli of 3D VRR stores will be generated, adapting Rosenbaum and Massiah's (2011) model into an expanded servicescape model.

This study is based on previous empirical work done in the context of traditional and web retail environments (Manganari et al., 2011; Ward et al., 2007; Eroglu et al., 2001; Donovan et al., 1994; Donovan and Rossiter, 1982), where researchers investigated how different retail environments affected shoppers' behaviour. This study is specifically parallel to the work of Eroglu et al. (2001) and aims at proposing a model to measure the effect of VRR stores' environmental cues on shoppers' behaviours.

A Stimulus-Organism-Response (SOR) model (Mehrabian and Russell, 1974) and an expanded servicescape model (Rosenbaum and Massiah, 2011) are adapted to provide a 3D servicescape model to measure 3D VRR environments. Although there is one known previous study (Vrechopoulos et al., 2009) in which researchers tried to investigate the effect of the layout of 3D VRR stores on shoppers' behaviours, they did not adapt Mehrabian and Russell's (1974) S-O-R model. Moreover, as argued by Lam (2001), a majority of the research investigating the effect of retail environments adapted an M-R (1974) model. Moreover, Vrechopoulos et al. (2009) also did micro-level research to investigate the effect of one environmental cue, such as layout and design, but the current research adapts a macro level approach to investigate the complete environment of 3D VRR stores and its effect on shoppers' behaviours, taking an S-O-R model as a basic framework.

This section has provided an extensive review of virtual worlds and virtual reality retailing. A gap in the research has also been discussed, which leads towards the development of a conceptual model for this research on the basis of an extensive theoretical review. The next chapter presents a conceptual model for this research, which is based on the up-to-date review of the existing servicescape models. Mehrabian and Russell's (1974) affect model is discussed along with Rosenbaum and Massiah's (2011) expanded servicescape 
model. The conceptual model was developed by adapting the M-R (1974) affect model, an expanded servicescape model and through interviews.

\section{THE CONCEPTUAL MODEL}

\section{A. Up-to-date Review of Servicescape Models}

To develop the proposed conceptual model of this study all well-known servicescape studies within the retail environment were considered. An attempt is made in this study to offer a review of all known contemporary research within the field since 1980. Research between 1980 and 1990 within the field of service environment and its effect on human behaviour are few in number. Among these few, the majority of the studies were done within the North American region (e.g., Milliman, 1986; Bellizzi et al., 1983; Milliman, 1982; Donovan and Rossiter, 1982; Russell, 1980), and one in Australia (Amato and McInnes, 1983). During that time period research was conducted using different methods; for instance, some research was self-reported (Russell, 1980), by description (Donovan and Rossiter, 1982), and through field studies (Milliman, 1986, 1982; Amato and McInnes, 1983). There were some other studies between 1986 and 1991 that conducted research into the retail environment and its effect on shoppers' behaviours, for example Bateson and Hui (1987) studied the effect of crowding within the service environment, while Bawa et al. (1989) investigated the effect of store environments on brand loyalty, and Lyer (1989) focused on the store environment and its effect on unplanned purchasing. However, these studies ignored the Mehrabian and Russell (1974) model. Yalch and Spangenberg (1990, 1988) conducted the only two studies during this time period (1986 and 1991) that adapted the Mehrabian and Russell (1974) affect model. These two studies were also conducted in North America, and were field studies.

One of the factors that caused a lack of studies in this area before 1990 was that researchers did not know the importance of the retail environment and its effect on shoppers' behaviour (Yalch and Spangenberg, 1988). Hence, Yalch and Spangenberg (1990) pointed towards the retail environment and its great effect on consumers' behaviours, and called on other researchers to explore the environmental cues of retail environments other than music and crowding, which had already been investigated in the past (Yalch and Spangenberg, 1990, 1988; Milliman, 1986, 1982). This call for more research in this area and motivated the researchers. During 1991 and 1999, sixteen research papers could be found focusing on the retail environment and its effect on consumers' behaviours (Kearney et al., 2007). Among these sixteen studies, a majority of them were again from the North American Region (Spangenberg et al., 1996; Wakefield and Blodgett, 1996; Herrington and Capella, 1996; Dube et al., 1995; Gulas and Schewe, 1994; Wakefield and Blodgett, 1994; Yalch and Spangenberg, 1993; Baker et al., 1992; Bellizzi and Hite, 1992; Kellaris and Kent, 1992). Out of the rest of them, four studies were from Europe (Foxall and Greenley, 1999; Kenhove and Desrumaux, 1997; Spies et al., 1997; Hui and Bateson, 1991); one from Australia (Donovan et al., 1994) and one from Hong Kong (Tai and Fung, 1997). During this time period the trend to use field experiments increased and nine out of sixteen studies (Foxall and Greenley, 1999; Tai and Fung, 1997; Kenhove and Desrumaux, 1997;Spies et al., 1997; Herrington and Capella, 1996; Wakefield and Blodgett, 1996;Donovan et al., 1994; Gulas and Schewe, 1994; Yalch and Spangenberg, 1993), focused on field studies/ field experiments; however, the other seven studies were done in laboratories (Spangenberg et al., 1996; Dube et al., 1995; Wakefield and Blodgett, 1994; Kellaris and Kent, 1992; Baker et al., 1992; Bellizzi and Hite, 1992;Hui and Bateson, 1991) A majority of the researchers (Herrington and Capella, 1996; Dube et al., 1995; Gulas and Schewe, 1994; Yalch and Spangenberg, 1993; Kellaris and Kent, 1992) again followed the footsteps of previous researchers and investigated the same environmental cue, music, which had been studied many times even before 1991 (Yalch and Spangenberg, 1998, 1998; Milliman, 1986, 1982). There are only a few studies, during this time period, which investigated the effect of environmental cues other than music. For instance Bellizzi and Hitte's (1992) study on colours, Spangenberg et al.'s (1996) on olfaction, and Spies et al.'s (1997) on two environmental cues at the same time: lighting and colours.

Studies during this time period also adapted Mehrabian and Russell's (1974) affect model to investigate the effect of retail environments on shoppers' behaviours. However, Foxall and Greenley (1999) were the first researchers who considered dominance as a mediating variable between environment and shoppers' behaviours, but finding had a vague relationship between stimuli and behaviour. Later, this was confirmed by Gilboa and Rafeli (2003) as they indicated that dominance was the weakest element in the organism dimensions of the M-R (1974) model, and could be ignored in future studies. Between 2000 and 2007, nineteen more studies are known to have been done (Kearney et al., 2007). These nineteen only include those studies that were done in brick and mortar environments and not in online retail environments. Thirteen (majority) studies were again done in the North American region (Morin et al., 2007; Mattila and Wirtz, 2006; Spangenberg et al., 2006; Spangenberg et al., 2005; Babin et al., 2003; Chebat and Michon, 2003; Hightower et al., 2002; Chebat et al., 2001; Dube and Morin, 2001; Mattila and Wirtz, 2001; Summers and Herbert, 2001; Machleit et al., 2000, Yalch and Sapangenberg, 2000), three studies were done in Europe (Newman, 2007; Bigne et al., 2005; Reimer and Kuehn, 2004), one in Israel (Gilboa and Rafaeli, 2003), one in Singapore (Wirtz, Mattila, and Tan, 2000) and one in Australia (Sweeney and Wyber, 2002). Ten out of nineteen studies were done in field experiments, which is almost half of the total (Newman, 2007; Morin et al., 2007; Machleit et al., 2000; Spangenberg et al., 2006; Bigne et al., 2005; Reimer and Kuehn, 2004; Chebat and Michon, 2003; Hightower et al., 2002; Dube and Morin, 2001; Mattila and Wirtz, 2001). The rest of the studies were done within the laboratory environment. Though music remained the most frequently studied environmental cue even during this time period (e.g. Mattila and Wirtz, 2001; Yalch and Sapngenberg, 2000), olfaction (Spangenberg et al., 2005 and 2006; Chebat and Michon, 2003; Mattila and Wirtz, 2001), colours (Chebat and Morin, 2007), and lighting (Summers and Herbert, 2001) also got more attention compared to previous studies. 
Until today, a majority of the research in retail environments has been conducted in North America and Europe. There are just a few studies done in other parts of the world, e.g., Malaysia, China and India.

\section{B. Servicescape Frameworks}

Serivcescape was first discussed by Kotler (1974) as a store atmospheric, and he argued that it is the store environment that is built to influence shoppers' behaviours so that sales can be increased. Bitner (1992) also defined servicescape as possessing all the physical factors of stores that are controlled by retailers in order to enhance or constrain customers' and employees' emotions and behaviours. Servicescape is also defined as possessing all the physical factors of stores that facilitate customers' shopping and communicating when in the store (Bitner and Zeithaml, 2003).

Servicescape is given a high level of importance in the literature on building customers' perceptions and expectations regarding the service being delivered (Grewal et al., 2003; Baker et al., 2002; Bitner, 1992). There are many frameworks to measure the service environments (Kearney et al., 2007) and these servicescape models are helpful in evaluating, assessing, measuring and understanding store environment and their atmospheres (Reimer and Kuehn, 2004; Turley and Milliman, 2000; Gulas and Schewe, 1994; Kellaris and Kent, 1992). Well known frameworks that measure the service environment are: the S-O-R model presented by Mehrabian and Russell (1974), cognitive theory by Lazarus (1991) and the servicescape model by Bitner (1992). Untill today, the most frequently adapted frameworks that measure the retail environment come from Mehrabian and Russell's (1974) S-OR framework and Bitner's (1992) servicescape model.

The main difference between M-R and Lazarus' cognition theory is that an M-R model adapts emotions to a cognition approach, whereas Lazarus's (1991) cognition theory supports the application of cognition to an emotional approach (Bigne, et al., 2005; Chebat and Michon, 2003). For a long time researchers supported both sides (Lin, 2004). Bigne et al. (2005) supports Mehrabian and Russell's (1974) emotions to cognition approach, whilst Chebat and Michon (2003) support Lazarus's (1991) cognition to emotions approach. However, arguments from both sides have research limitations; hence more research was called for by Bigne et al. (2005).

This researcher is supporting Mehrabian and Russell's (1974) emotions-cognition approach, with a strong rationale outlined below.

\section{The Mehrabian and Russell Affect Model}

In 1974 Albert Mehrabian and James A. Russell proposed an affect model in their book titled 'An Approach to Environmental Psychology'. That affect model went on to become well respected in the field of environmental psychology and marketing. Researchers adapted it again and again in their research. Mehrabian and Russell's (1974) affect model proposed that every built or physical environment affects human behaviour through the intervening variables of emotions. This model contains three dimensions known as stimuli (S), which include the environment and all the environmental cues; organism $(\mathrm{O})$, which here contains three emotions, which are pleasure, arousal and dominance; and a response (R) dimension, which comprises of human behaviour (approach and avoidance). That is why this M-R model is often called an S-O-R model. This approach from environmental psychology has been adapted in different studies to measure the specific environment and its effect on human behaviour (Harrell and Hutt, 1976; Lutz and Kakkar, 1975; Belk, 1974). However, it is not known if it was adapted as an overall framework in a retail setting until Donovan and Rossiter adapted the M-R affect model in 1982. An initial illustration of Mehrabian and Russell's (1974) model is given below in Figure 1.

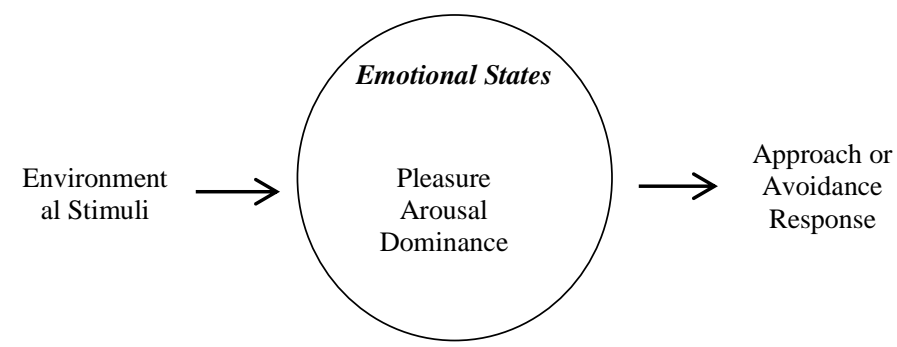

Fig. 1. Mehrabian and Russell affect model. Adapted from An Approach to Environmental Psychology (p. 8) by A. Mehrabian., \& J. A. Russell, 1974, Cambridge, MA: MIT Press. Copyright 1974 by The Massachusetts Institute of Technology. Adapted with permission

The rationale behind adapting the Mehrabian and Russell (M-R) model is that not only does it provide an appropriate framework to base the measurement of the retail environment and shoppers' emotions and behaviours on (Quartier, 2011), but it also helps in measuring possible emotional responses by combining the basic PAD emotional dimensions (Graa and Dani-elKebir, 2011). It is also claimed that this model could be used to measure the effect of any built environment (Russell, 1980; Russell and Pratt, 1980; Mehrabian and Russell, 1974). Researchers have already adapted this model to measure both traditional retail environments: brick and mortar and click and mortar (Quartier, 2011; Kim and Lennon, 2010; Donovan and Rossiter, 1982). Therefore, in this research an M-R affect model is assumed to provide a base to measure 3D VRR environments and shoppers' behaviours within them.

The M-R model is adequate to measure emotions, but it is weak in the stimulus taxonomies area and researchers need to develop new stimulus taxonomies to measure relationships between intervening variables (Newman, 1997; Donovan and Rossiter, 1982). Mehrabian and Russell (1974) argued that different environments have different environmental cues and each environment is different from the other. Therefore, a stimuli section of the S-O-R framework was left vague as this dimension needs more experimental research to generate the taxonomy of the specific environment. Though researchers in the past developed different models to measure physical settings and generate stimulus taxonomies for different environments as discussed above, Bitner (1992) coined the term 'servicescape' for the first time to cover this area specifically. Later, other researchers developed other models to measure environments and the stimulus taxonomy for those specific environments (Williams and Dargel, 2004 etc.). Bitner (1992) separated environmental cues into three 
dimensions: ambient cues; spatial and functional cues; and signs, symbols and artifacts. However, Bitner's (1992) servicescape framework itself originated from ecological theory, which was presented in the early 1900s by Darwin and later, gave the foundation to Barker's (1968) study in the field of environmental psychology (Stokols, 1972).

Bitner's (1992) servicescape model has been adapted by many researchers; however, it has not been without its problems. Later, in 2011, Rosenbaum and Massiah (2011) conducted a contemporary review of all the existing servicescape models and proposed another servicescape framework, which is based on Bitner's (1992) original servicescape model. This model is also known as an Expanded Servicescape Model. Rosenbaum and Massiah's (2011) expanded their servicescape model to take into consideration the study of Proshansky (1978). They proposed that the service environment not only includes physical dimensions but also comprises social, socially symbolic and natural dimension, and all these dimensions influence shoppers' and employees' behaviour.

As a result, an 'expanded' servicescape model (Rosenbaum and Massiah, 2011; pp. 473) is adapted in this research in an attempt to define the stimulus dimension of an M-R (1974) model. This expanded servicescape model illustrates four environmental dimensions: physical, social, socially symbolic, and natural stimuli. Researchers (Rosenbaum and Massiah, 2011) illustrated in this model that merely objective, measureable and managerially controllable environmental cues are not the part of servicescapes. However, social, socially symbolic, and natural environmental cues, which are not controllable by retailers, are part of servicescapes. The aim is to adapt this model to fit a VRR environment and attempt to define VRR stores' environmental stimuli.

\section{Developing a 3D Servicescape Model}

Rosenbaum and Massiah's model was presented in the context of a brick and mortar retail environment, and although a 3D VRR environment has many similarities with a brick and mortar retail environment, it also differs in many ways. Shoppers can fly and teleport in VRR store environments, which is not possible in physical brick and mortar environments (Vrechopoulos et al., 2009). As mentioned earlier, to define the stimulus dimension of an M-R model in this research, Rosenbaum and Massiah's model will be adapted, although it is not completely compatible with a 3D retail environment because it is a simulated environment. A $3 \mathrm{D}$ retail environment has different features, and it is an electronic environment that a customer enter through your electronically simulated body, called an avatar, rather than with a customer's real bodies. Therefore, assuming all these differences, this research needs to alter Rosenbaum and Massiah's (2011) expanded servicescape model through detailed interviews with university students. Eight participants were invited to attend a session in a designated research office that was suitable for conducting interviews, and they were invited to attend at different times and on different days. Four female and four male participants took part in this research, their ages being between 21 and 33 years. Participants were, initially, informed about virtual worlds, their usage, benefits and how to use them. Later on they were requested to make their own accounts in Second Life. Then they were requested to $\log$ in by using 'Second Life Viewer', which was available to them on a computer in the research office.

The computer in the research office was tested for its ability to run Second Life and whether the internet speed was able to support its smooth running. If the internet speed had dropped at any time when a participant was using Second Life the session would have been closed; in this case the participant would have been excused and a different student invited in to participate in the experiment. If a participant encountered any difficulties whilst experiencing Second Life, they would have had a negative experience due to time wasting and being in an irritating situation. However, during these eight detailed sessions to define the retail environment of 3D VRR stores by adapting an expanding servicescape model as an initial framework, not a single problem was faced regarding internet speed. All the sessions were successful and raised much interest amongst those willing to participate. Each participant received a 10 to 15 minute explanation of virtual worlds, especially those in Second Life. They were also given a brief outline of the research. It was not explained to the participants that the purpose of these sessions was to define the environment because it was assumed that if the participants were informed of this, later on after experiencing the 3D VRR environment when they were asked about the environmental cues they experienced in Second Life they would have been more conscious of them. This may have resulted in results bias. The participants were allowed to enter into the environment freely, and later on they were asked different detailed questions about being in the environment. Participants were requested to experience $3 \mathrm{D}$ VRR stores for at least 20 minutes, but there was no maximum time limit. Participants were allowed to leave the session whenever they wanted to, but none of the eight participants left the session before it was completed. They were offered tea or coffee, biscuits and sandwiches at the end of the session.

Participants were initially asked about their overall experience within Second Life. Five out of eight participants said it was really fascinating and they had enjoyed it. Moreover, none of the participants said they had wasted their time as at least they had experienced something new. It was noticed that those three participants who did not find Second Life a fascinating simulated world were not technology oriented. It is therefore also possible that they did not find it fascinating because they were not able to enjoy and experience all the features of Second Life.

After this, all eight participants were individually asked about virtual reality retail stores. They were asked what they saw in the VRR stores and how they compared VRR stores to physical stores (Brick and Mortar). Most of the participants (6 out of 8) said they found VRR stores to be more interesting and less boring. During this question and answers session, participants named many cues that they had experienced in the VRR store environments. All the environmental cues that were mentioned in Rosenbaum and Massiah's (2011) servicescape model and that were experienced by participants were marked on the model by the researcher. Later on, all those cues that were experienced and mentioned by the participants but were not present in Rosenbaum and Massiah's 


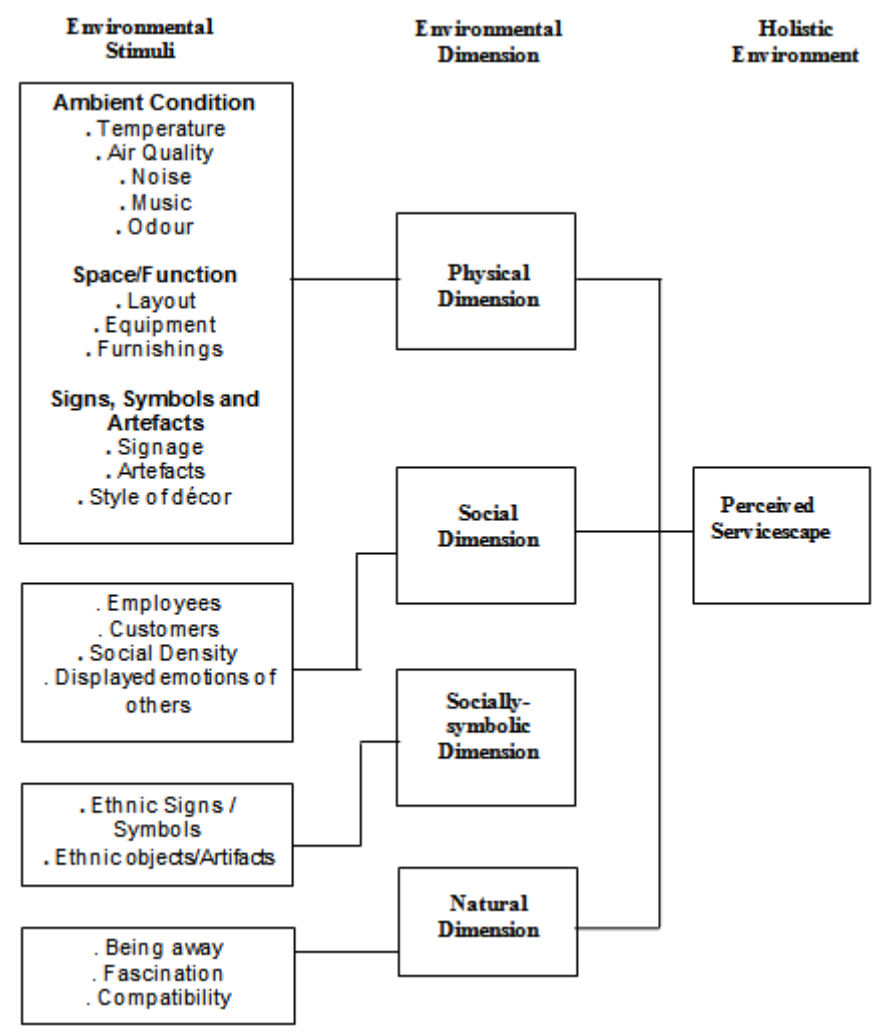

Fig. 2. An Expanded Servicescape Model for Understanding Four Environmental Dimensions of the Retail Environment. Adapted from "An expanded servicescape perspective" by M. S. Rosenbaum., \& C. Massiah, 2011, Journal of Service Management, 22(4), p. 473. Copyright 2011 by Emerald Group Publishing Limited. Adapted with permission

model were added into the model, for example: being able to teleport, virtual air, flying etc. Details of these cues are given in the Stimulus section of this model. The purpose of these interviews was to confirm the stimuli dimension of the conceptual model. The finalized conceptual model is given in Figure 3. Participants agreed that the concept of an electronic virtual world and a virtual reality retail store was quite good. Although it is easy to use Second Life, participants still said they needed some practice before they became able to use all of the features that would make their shopping process easier.

\section{- Stimulus $(S)$ :}

According to M-R (1974), the stimulus dimension of the S-O-R framework is the one that affects human emotions, and the effect on emotions further leads to changes in behaviour. In the context of VRR stores in this conceptual model, it is assumed that stimulus is the sum total of all the environmental cues that are audible and visible to virtual shoppers. There are many environmental cues in VRR stores that are absent in traditional retail stores; for example, avatars in VRR stores can fly around the store (Vrechopoulos et al., 2009). There are some environmental cues in VRR stores that are similar to those in a traditional retail environment and absent in traditional online retailing. For example, Eroglu et al. (2001) determined that in contrast to the VRR environment an online retail environment lacks a visible presence of other shoppers and employees.

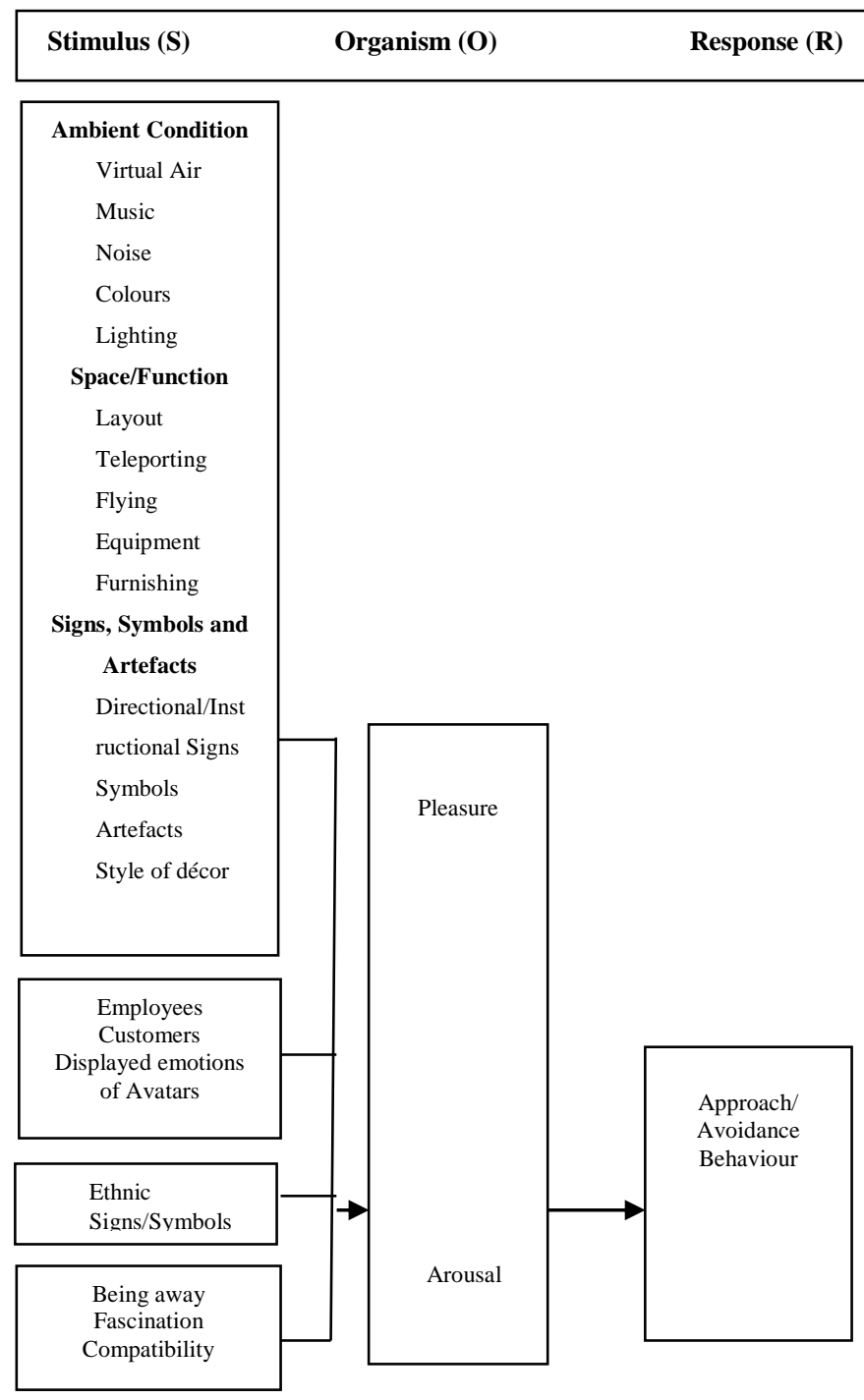

Fig. 3. The Proposed Conceptual Model of Shoppers' Behaviour in 3D VRR Store

It is obvious and easy to understand that a VRR store environment lacks some characteristics of a traditional retail store environment, such as three (sense of touch, sense of smell, sense of taste) of the five sensory appeals (Vrechopoulos et al., 2009). However, there is perhaps no doubt that a VRR store environment is far better than that of the traditional online retail stores because it more closely replicates the environment of a traditional brick and mortar retail environment (Vrechopoulos et al., 2009). Ostensibly, a VRR store's whole environment is limited to the computer screen, like that of traditional online retail stores (Eroglu et al., 2001), but in reality it is more than that. As explained earlier, in a VRR retail environment, shoppers, through their avatar, can walk around the store, can see, chat and communicate with other avatars, thus proving it to be a pure replication the environment of traditional brick and mortar retail stores (Vrechopoulos et al., 2009). Hence, the classification of the traditional online retail store environment is not applicable to that of VRR stores, for which an alternative taxonomy is 
necessary. Since the VRR store has more in common with the traditional retail store, so the taxonomy development should also be parallel to that of the traditional retail environment. Hence, an expanded servicescape model presented by Rosenbaum and Massiah (2011) is adapted in this research. Bitner (1992) proposed three dimensions of servicescape, which were physical, social and natural stimuli. However, the expanded servicescape model of Rosenbaum and Massiah (2011) consists of socially symbolic dimensions other than physical, social and natural stimuli.

Physical Dimension: Physical dimensions consist of three main environmental cues, which are ambience, space/function, signs, symbols and artifacts. Ambient conditions are temperature, air quality, noise, music and odour. In the past, there were studies in brick and mortar retail environment where researchers explored the effect of temperature and odour on shoppers' shopping behaviour (Ward et al., 2007; Spangenberg et al., 2006; Spangenberg et al., 1996; Michon et al., 2005; Spangenberg et al., 2005; Chebat and Michon, 2003; Mattila and Wirtz, 2001; Yalch and Spangenberg, 2000). However, there is no concept of temperature and odour in online web stores and hence there is no study found in this context. The same is the case with virtual reality retail store environment, which are 3D but computer based and hence users cannot experience any smell or temperature. Therefore, these two cues of ambient conditions were eliminated in the process of adapting this model in a VRR environment context. However, in virtual worlds (e.g., Second Life) there is a presence of virtual air and artificial simulated weather (summer or winter, wind or storm etc.), therefore the air quality cue is replaced by virtual air.

Space/Function consists of layout, equipment and furnishing. There are a few well known studies in brick and mortar (Nath, 2009; Ryu and Jang, 2008; Countryman and Jang, 2006; Li, 2004; Yalch and Spangenberg, 2000; Wakefield and Blodgett, 1996) and click and mortar (Manganari et al., 2011; Vrechopoulos et al., 2004) retail environments that have discussed stores' layout and its effect on shoppers' behaviour. This concept of store layout is present in 3D virtual reality retail stores as well, and one contemporary study has been found in this area too. Vrechopoulos et al. (2009) explored the different form of store layouts in 3D VRR stores environment and their effect on shoppers' behaviour. Krasonikolakis et al. (2011) have also considered layout as an important environmental cue of VRR stores. However, Vrechopoulos et al. (2009) argued that layout has no effect on consumers' behaviour in Second Life (SL) because of the shoppers' ability to fly and teleport in SL. Thus, teleport and flying is added to the section of Space/Function. MacKenzie et al. (2013) described the function of teleporting as moving an avatar from one part in the virtual world to another. Users' flying ability is enabled in Second Life and they can experience flying inside the store too. Vrechopoulos et al. (2009) argue in the results of their study that the layout of a VRR store might not have an effect because of the ability to fly. It suggests that this ability could affect shoppers' emotions and behaviour; therefore, flying is added in the conceptual model of this research to investigate its effect further.
Rosenbaum and Massiah (2011), while explaining their work, argued that retailers use signs to deliver general messages to customers, such as symbols and artefacts for communicating and decoration purposes in a retail environment. These environmental cues are also adapted in the conceptual model of this research as signs, symbols, and artefacts are seen and experienced by participants at the time of the model confirmation process. Hence, parallel to the set of propositions from Eroglu et al. (2001) and Bitner (1992) concerning the 3D servicescape, this research offers a number of propositions about 3D virtual reality retail environments. It is postulated that:

P1a: A 3D virtual reality retail store consists of physical dimensions

P1b: The physical dimensions of a 3D VRR store affect shoppers' approach/avoidance behaviour through the mediating variables of emotions (pleasure and arousal).

Social Dimension: The social dimension of an expanded servicescape model contains employees, customers, social density and the displayed emotions of others. Since there is no visible presence of employees and customers in traditional online retail environments, as explained by Eroglu et al. (2001), there is therefore no social density. That is why researchers focusing on an online retailing context have ignored the social dimension and its effect on shoppers' emotions and behaviours. However, in brick and mortar retail environments there is a wide concept of social factor and a large amount of research has been done in this area already (Lin and Liang, 2011; Dion, 2004; Wang, 2003; Baker et al., 2002; Sherman et al., 1997; Baker et al., 1994; Baker et al., 1992). Likewise, shoppers can see other avatars in virtual worlds while shopping in 3D VRR stores, they can also chat (by text) and Voice Over Internet Protocol (VOIP) with each other as well.

There is a concept of social factors in virtual worlds and it has been appreciated by the participants in past research (for example, Hassouneh and Brengman, 2011). Shopping in virtual worlds is perceived as more fun, with no crowds or rude people. However, none of the seven participants in this study experienced any employees inside the VRR stores, and the same was the case with Hassouneh and Brengman (2011). Hence, it was decided that researchers would act as employees in VRR stores during the main study, and other participants in the main study would be acting as customers to each other.

It is assumed that the presence of a social factor in virtual reality retail stores should have some effect on shoppers' emotions and behaviour. Additionally, research claims that there is an obvious display of emotions among avatars as they show their anger or pleasure through their faces (Lee et al., 2013). Although all these eight participants, in this research, did not notice any avatar's emotions, despite this Avatars' displayed emotions, has been adopted in the social dimension of this conceptual model by following Lee et al.'s (2013) research, As a result, the social dimension of the conceptual model includes customers, employees and displayed emotions of other avatars. Hence it is posited that: 
P2a: A 3D virtual reality retail store consists of social dimensions

P2b: The social dimensions of a 3D VRR store affects shoppers' approach/avoidance behaviour through the mediating variables of emotions (pleasure and arousal).

Socially symbolic dimension: The socially symbolic dimension of the model consists of ethnic signs/symbols and ethnic objects/artefacts. These environmental cues of socially symbolic dimensions were considered as integral cues of the servicescape dimension in previous studies (Bitner, 1992). Bitner (1992) and Rosenbaum (2005) argued that managers try to influence shoppers' approach or avoidance behaviour through ethnic signs and symbols because these ethnic signs and symbols reflect affiliation with the shoppers. They could have either a positive or negative (if perceived negatively by customers) effect on shoppers' emotions and, consequently, on their subsequent behaviour. Since most of the participants noticed ethnic signs and symbols in VRR stores, ethnic signs and symbols were added in this conceptual model within the socially symbolic section (as shown above in figure 3 ). Therefore, it is posited that:

P3a: A 3D virtual reality retail store consists of socially symbolic dimensions.

P3b: The socially symbolic dimensions of 3D VRR store affect shoppers' approach/ avoidance behaviour through the mediating variables of emotions (pleasure and arousal).

Natural Dimension: The natural dimension of an expanded servicescape model consists of three stimuli: being away, fascination, and compatibility. Arguing about the first stimuli of this dimension, Rosenbaum and Massiah (2011) posited that being away does not really mean being physically away from one's place of existence. Rather it is the feeling of being away from one's work routine and experiencing a sense of relaxation and enjoyment. Jin and Bolebruch (2009), Wyld (2010) and Melancon (2011) are all of the opinion that virtual worlds are immersive enough to make a user forget about his or her real identity through the adoption of a virtual identity (Avatar). Therefore, it is assumed that virtual worlds give users the feeling of being away. This stimulus is also included in this model in the VRR store context. Since Virtual worlds also provide a fascinating environment (Melancon, 2011) so this stimulus is presumed to have an effect on shoppers' emotions and behaviours. VWs are a gift from technology and predominantly technology-oriented people are able to use them in the home environment. Compatibility is, therefore, an important stimulus to be investigated in the context of research into VRR stores' environments. That is why this third and last stimulus is also included in the natural dimension of this proposed model of shoppers' behaviours in VRR store environments. Hence, it is postulated that:

P4a: A 3D virtual reality retail store consists of natural dimensions.

P4b: The natural dimensions of 3D VRR stores affect shoppers' approach/avoidance behaviour through the mediating variables of emotions (pleasure and arousal).

\section{- $\operatorname{Organism}(O)$}

In an S-O-R model, the organism dimension shows the human emotional state (M-R, 1974). Mehrabian and Russell (1974) posited that all human emotions could be placed into three categories, which they called Pleasure, Arousal, and Dominance, and are often referred to as the PAD dimensions. It is also hypothesised that each environment, including a retail environment, affects an individual's state of pleasure, arousal and dominance (Mehrabian and Russell, 1974).

This PAD dimension is orthogonal:

Pleasure - Displeasure

Arousal - No arousal

Dominance - Submissiveness

Later, in 1980, Russell and Pratt modified this S-O-R model and deleted the dominance dimension from the organism section of the model. They argued that dominance requires interpretation by the individual and could not be included in a situation where effective responses are required. Although initially the dominance dimension was included in much retail environment research (traditional and online), it was later excluded at the time of final studies (Quartier, 2011; Eroglu et al., 2001; Donovan and Rossiter, 1982). Hence, in this research the dominance element is also excluded from organism dimensions of the model. The rationale behind ignoring the dominance dimension in this research is Mehrabian and Russell's (1974) study in which they themselves did not pay much attention to dominance. Later, other researchers also supported it by ignoring and declaring dominance as a less beneficial dimension (Quartier, 2011; Sweeney and Wyber, 2002; Eroglu et al., 2001; Dube et al., 1995; Donovan et al., 1994; Amato and McInnes, 1983; Donovan and Rossiter, 1982; Russell, 1980).

In a majority of research results have supported both pleasure and arousal as an important predictor of behaviour; however, some research has also contradicted this (e.g. Kearney et al., 2007). Moreover, Donovan et al. (1994) found arousal insignificant in a pleasant retail environment, which contradicts Donovan and Rossiter's (1982) study of the retail environment. Along with many other reasons for this contradiction, it is also possible that it is due to a difference in sample size and methodological approach. Donovan and Rossiter (1982) used a small sample size, whilst Donovan et al. (1994) used a larger sample size alongside a field study. Kenhove and Desrumaux (1997) supported previous research (Donovan et al., 1994; Donovan and Rossiter, 1982) and argued that indeed Mehrabian and Russell's (1974) model fits well in retail settings. They confirmed that an organism plays an important role of mediator between the environment and shoppers' behaviour. However, previous studies (Donovan et al., 1994; Donovan and Rossiter, 1982) only stressed the importance of pleasure, while Kenhove and Desrumaux (1997) confirmed the importance of arousal as well. This result was later confirmed by Tai and Fung (1997) who found a partial relationship between pleasure and arousal in their study. Hence it is posited that: 
P5: The pleasure and arousal state of virtual shoppers mediates the relationship between 3D VRR store environments and shoppers' behaviour (approach/avoidance).

P6: There is an interrelationship between pleasure and arousal as mediating variables when predicting the effect of a 3D VRR environment on shoppers' behaviour.

\section{- Response (R)}

Mehrabian and Russell's (1974) S-O-R model consists of a response dimension, which in a VRR store environment context shows how the shoppers' final response is affected by the VRR store environment through PAD (Pleasure-ArousalDominance) dimensions as an intervening variable (Quartier, 2011; Eroglue et al., 2001 \& 2003; Sherman et al., 1997; Donovan and Rossiter, 1982). The response dimension consists of approach and avoidance behaviour. Approach behaviour reflects all the positive behaviours towards any particular retail environment in contrast to avoidance behaviour, which represents all the negative intentions/actions towards that particular retail environment. Therefore:

P7: Virtual shoppers' positive emotional states lead to approach behaviour in a 3D VRR store environment such as revisiting the store, spending more money, staying for longer etc.

P8: Virtual shoppers' negative emotional states lead to avoidance behaviour in a 3D VRR store environment such as leaving the store as soon as possible, never visiting it again, lower spending etc.

\section{CONCLUSION}

After the text edit has been completed, the paper is ready for the template. Duplicate the template file by using the Save As command, and use the naming convention prescribed by your conference for the name of your paper. In this newly created file, highlight all of the contents and import your prepared text file. You are now ready to style your paper; use the scroll down window on the left of the MS Word Formatting toolbar.

\section{A. Research Implications}

This research opens a number of new avenues for further investigation through the proposed model of shoppers' behaviour in a VRR store environment. As aforementioned, there is one known research (Vrechopoulos et al., 2009), which attempted to explore the VRR store environment and its effect on shoppers' behaviour. This research was at a micro level, where the researchers tried to explore the effect of layout on shoppers' behaviour in VRR store environments. However, the present research represents the first step to explore the VRR store environment through holistic (molar approach according to Quartier, 2011) approach where all the environmental cues of a VRR store environment are considered. Further, a systematic taxonomy development of VRR store environment is attempted through this proposed model that may prove to be the main step in theory building. It is thus assumed that this research opens ample opportunities in future for theoretical and empirical research into VRR store environments. This model, through its propositions and each of the relationship between variables, offers an avenue of further in-depth research to future researchers.

As described earlier a number of researchers (Quartier, 2011; Eroglu et al., 2001 and 2003; Donovan and Rossiter, 1982) in the retail environment area, who adapted the S-O-R model of Mehrabian and Russell (1974), argued that this (S-O$\mathrm{R})$ model is weak in its Stimulus (S) dimension and there is a dire need to focus on the taxonomy development stage. As it is clear that a VRR store environment provides a more simulating environment to the traditional retail environment (Brick and Mortar) than that of traditional online retail stores; hence taxonomy developed by traditional online retail environment researchers is not fully applicable to the VRR environment. Therefore, in this proposed model an expanded servicescape model (Rosenbaum and Massiah, 2011) is adapted in the Stimulus dimension of S-O-R model.

In a nutshell, this conceptual model proposes as a first step to theorise the environmental cues and shoppers' responses in a VRR store context holistically. As mentioned above, both VWs and virtual users are growing in number very rapidly; therefore, it is assumed that VRR stores will emerge as a new channel of retailing and attain greater attention from academics and practitioners. This vibrant area is open to be explored by researchers for their theoretical and methodological contributions.

\section{B. Future Studies}

This research filled the gap in the knowledge and provided a 3D servicescape conceptual model which defines the 3D VRR store environment in depth. However, the environment was defined through eight detailed interviews and this limits the extent to which it can be generalised. It is possible that there is no effect of some environmental cues on shoppers' emotions and behaviour. It is proposed that the adapted Stimulus dimension (Rosenbaum and Massiah, 2011) would be appropriate to measure a VRR store environment; however, further detailed research is needed in this area. Other moderating and intervening variables (e.g. involvement and atmospheric responsiveness, from Eroglu et al., 2001) can also be considered in future research. Further empirical research is necessary to confirm the effect of 21 environmental cues of the 3D servicescape conceptual model on shoppers' behaviour through the mediating variables of emotions. This research calls for quantitative research in a controlled lab environment where the propositions made in this paper should be tested.

\section{REFERENCES}

[1] Adolph, M. (2011). Trends in Video Games and Gaming. Retrieved from ITU-T Technology Watch Report. URLhttp://ocw.metu.edu.tr/pluginfile.php/10647/mod_resource/content/ 1/T23010000140002PDFE.pdf (accessed 12 August, 2015) 
[2] Amato, P. and McInnes, I. (1983), “Affiliative Behaviour in Diverse Environments: A consideration of Pleasantness, Information Rate, and the Arousal-Eliciting Quality of Settings", Basic and Applied Social Psychology, Vol. 4, No. 2, pp. 109-122.

[3] Auden, W. H. (1968), Secondary Worlds: Essays. Random House.

[4] Babin, B. J., Hardesty, D. M. and Suter, T. A. (2003), "Color and Shopping intentions: The intervening effect of price fairness and perceived affect", Journal of Business Research, Vol. 56, pp. 541-551.

[5] Bateson, J.E.G., and Hui, M.K.M. (1987), "A model for crowding in the service experience: empirical findings", The Services Challenge: Integrating for Competitive Advantage, pp. 85-89.

[6] Bainbridge, W.S. (2007), "The Scientific Research Potential of Virtual Worlds", Science, Vol. 317, No. 5837, pp. 472-476

[7] Baker, J., Levy, M., and Greval, M. (1992), "An experimental approach to making retail store environmental decisions", Journal of Retailing, Vol. 68, No. 4, pp. 445-46.

[8] Baker, J., Parasuraman, A., Grewal, D. and Voss, G. (2002), "The Influence of multiple store environment cues on perceived merchandise value and patronage intentions", Journal of Marketing, Vol. 66, pp. 120141

[9] Barnes, S. and Mattsson, J. (2008), "Brand Value in Virtual Worlds: An Axiological Approach", Journal of Electronic Commerce Research, 9 (3), 195-207.

[10] Barker, R. G. (1968), "Explorations in ecological psychology", American Psychologist, Vol. 20, pp. 1-14

[11] Bawa, K., Landwehr, J.T. and Krishna, A.A. (1989), "Consumer response to retailers' marketing environments: an analysis of coffee purchase data", Journal of Retailing, Vol. 65, No. 4, pp. 471-495

[12] Bellizzi, J. A., Crowley, E.A. and Hasty, R.W. (1983). "The effects of Color in Store Design", Journal of Retailing, Vol. 59, No. 1, pp. 21-45.

[13] Bellizzi, J.A. and Hite, R.E. (1992), "Environmental Color, Consumer Feelings, and Purchase Likelihood", Journal of Psychology and Marketing, Vol. 9, No. 5, pp. 347-63.

[14] Belk, R.W. (1974), "Application and Analysis of the Behavioral Differential Inventory for Assessing Situational Effects in Buyer Behavior", In NA - Advances in Consumer Research, 01, pp. 370-380

[15] Bigne, J., Andreu, L. and Gnoth, J. (2005), "The Theme park experience: An analysis of pleasure, arousal and satisfaction" Tourism Management, Vol. 26, pp. 833-844.

[16] Bitner, M. J. (1992), "Servicescapes: The impact of physical surroundings on customers and employees", Journal of Marketing, Vol. 56, pp. 57-71.

[17] Bitner, M. J. and Zeithaml, V. A. (2003), Services Marketing integrating customers focus across the firm ( $\left.3^{\text {rd }} \mathrm{ed}\right)$, McGraw Hill, New York

[18] Centre for retail research (2013). "Retail in 2018 - Shop numbers, Online and the High Street", accessed from www.retailresearch.org/retail2018.php_(accessed on 15 August, 2015)

[19] Chang, G. (2014), "Top Innovations that Changed the Worlds of Retail", RIS Retail Info Systems NEWS, accessed from http://risnews.edgl.com/retail-news/Top-Innovations-that-Changed-theWorld-of-Retail94709 (accessed on 23 August 2015)

[20] Chebat, J.C., Chebat, C.G. and Vaillant, D. (2001), "Environmental Background music and in-store selling", Journal of Business Research, Vol. 54, pp. 115-123.

[21] Chebat, J. C. and Michon, R. (2003), "Impact of ambient odors on mall shoppers' emotions, cognition, and spending: A Test of Competitive causal theories", Journal of Business Research, Vol. 56, pp. 529-39.

[22] Countryman, C.C., and Jang, S. (2006), "The effects of atmospheric elements on customer impression: the case of hotel lobbies", International Journal of Contemporary Hospitality Management, Vol. 18, No. 7, pp. 534-545

[23] Craik, K. H. (1973). "Environmental Psychology", Annual Review of Psychology. Vol. 23, pp. 403-422

[24] Davis, L., Wang, S. and Lindridge, A. (2008), "Culture Influences on emotional responses to on-line store atmospheric cues", Journal of Business Research, Vol. 61, pp. 806-812.
[25] Dion, D. (2004). "Personal control and coping with retail crowding", International Journal of Service Industry Management. Vol. 15, No. 3, pp. 2250-263.

[26] Donovan, R.J., and Rossiter, J.R. (1982), "Store atmosphere: an environmental psychology approach", Journal of Retailing, Vol. 58, No. 1, pp. 34-57.

[27] Donovan, R.J., Rossiter, J.R., Marcoolyn, G., \& Nesdale, A. (1994), "Store atmosphere and purchasing behaviour", Journal of Retailing, Vol. 70, No. 3, pp. 283-294.

[28] Dooley, J.A., Jones, S.C. and Iverson, D. (2012), "Web 2.0: an assessment of social marketing principles", Journal of Social Marketing, Vol. 2, No. 3, pp. 207-221

[29] Dube, L., Chebat, J.C. \& Morin, S. (1995), "The Effects of Background Music on Consumers' Desire to Affiliate in buyer-Seller Interactions", Psychology and Marketing, Vol. 12, No. 4, pp. 305-319.

[30] Dube, L. \& Morin, S. (2001), "Background music pleasure and store evaluation Intensity effects and psychology mechanisms", Journal of business Research, Vol. 54, pp. 107-113.

[31] Dunne, P.M., Lusch, R.F. and Griffith, D.A. (2002), Retailing ( $4^{\text {th }}$ ed.), South-Western Educational Publishing, Mishawaka, IN, USA

[32] eMarketer (2014), "Total US Retail Sales Top \$4.5 Trillion in 2013, Outpace GDP Growth", Retrieved from www.emarketer.com/Article/Total-US-Retail-Sales-Top-3645-Trillion2013-Outpace-GDP-Growth/1010756 (accessed on 26 November 2015).

[33] Eroglu, S.A., Machleit, K.A., and Davis, L.M. (2001), "Atmospheric qualities of online retailing: a conceptual model and implications", Journal of Business Research, Vol. 54, pp. 177-184.

[34] Eroglu, S.A., Machleit, K.A., and Davis, L.M. (2003), "Empirical testing of a model of online store atmospherics and shopper response", Psychology and Marketing, Vol. 20, No. 2, pp. 139-50.

[35] Foxall, G. \& Greenley, G. (1999), “Consumers' Emotional Responses to Service Environments", Journal of Business Research, Vol. 46, pp. 149158.

[36] Gartner. (2007), "Gartner Says 80 Percent of Active Internet Users Will Have A "Second Life" in the Virtual World by the End of 2011", Technology Research Gartner Inc. Available from www.gartner.com/it/page.jsp?id=503861_(accessed 11 November, 2015)

[37] Graa, A., and Dani-elKebir, M. (2011), "Situational factors influencing impulse buying behavior of algerian consumer" RRM, Vol. 2, pp. 52-59.

[38] Gibbs, S. (2015), "Apple Pay launches in the UK: here's how to use it", Theguardian, Retrieved November, 2015 from www.theguardian.com/technology/2015/jul/14/apple-pay-launches-ukhow-to-use (accessed 13 November, 2015).

[39] Gilboa, S. and Rafaeli, A. (2003), "Store environment, emotions and approach behaviour: applying environmental aesthetics to retailing", International Review of Retail, Distribution and Consumer Research, Vol. 13, pp. 195-211.

[40] Graves, P. (2013), Consumer.ology. Nicholas Brealey Publishing, London

[41] Gulas, C. S. and Schewe, C. D. (1994), "Atmospheric segmentation: Managing Store Image with Background Music", In R. Acrol and A. Mithcell (Eds.) Enhancing Knowledge Development in Marketing (pp. 325-330). American Marketing Association, Chicago, IL

[42] Haeckel, S. H. (1998), "About the nature and future of interactive marketing", Journal of Interactive Marketing, Vol. 12, No. 1, pp. 63-71.

[43] Haenlein, M., and Kaplan, A.M. (2009), "Flagship brand stores within virtual worlds: the impact of virtual store exposure on real-life attitude toward the brand and purchase intent", Researche et Applications en Marketing, Vol. 24, No. 3), pp. 57-79.

[44] Hassouneh, D. and Brengman, M. (2011), "Shopping in Virtual Worlds: Perceptions, Motivations, and Behavior", Journal of Electronic Commerce Research, Vol. 12, No. 4, pp. 320-335

[45] Hassouneh, D., and Brengman, M. (2015), "Retailing in social virtual worlds: developing a typolog of virtual store atmospherics", Journal of Electronic Commerce Research, Vol. 16, No. 3, pp. 218-241.

[46] Harrell, G.D. and Hutt, M.D. (1976), "Crowding in Retail Stores", M.S.U. Business Topics, pp. 33-39. 
[47] Herrington, J.D. and Capella, L.M. (1996), "Effects of Music in Service Environments: A Field Study", Journal of Services Marketing, Vol. 10, No. 2, pp. 26-41

[48] Hightower, R., Brady, M.K. and Baker, T.L. (2002), "Investigating the role of the physical environment in hedonic service consumption: an exploratory study of sporting events", Journal of Business Research, Vol. 55, pp. 697-707.

[49] Hunter, R., and Mukerji, D.B. (2011), "The role of atmospherics in influencing consumer behaviour in the online environment", International Journal of Business and Social Science, Vol. 2, No. 9, pp. 118-125.

[50] Hui, M.K. and Bateson, J.G. (1991), "Perceived control and the effects of crowding and consumer choice on the service experience", Journal of Consumer Research, Vol. 18, pp. 174-184.

[51] Jin, S.A., and Bolebruch, J. (2009), "Avatar-based advertising in second life: the role of presence and attractiveness of virtual spokespersons", Journal of Interactive Advertising, Vol. 10, No. 1, pp. 51-60.

[52] Kalla, S.M., and Arora, A. (2011), "Impulse Buying: A literature Review", Global Business Review, Vol. 12, No. 1, pp. 145-157.

[53] Kearney, T., Kennedy, A. Coughlan, J. (2007), "Servicescapes: A review of contemporary empirical research" Annual Frontiers in Service Conference, San Francisco, CA, pp. 58-88.

[54] Keeney, R.L. (1999), "The value of internet commerce to the consumer", Management Science, Vol. 45, No. 4, pp. 533-542

[55] Kellaris, J.J. and Kent, R,J. (1992), "The influence of Music on Consumers' Temporal Perceptions: Does Time Fly When You're Having Fun?", Journal of Consumer Psychology, Vol. 1, No. 4, pp. 365376.

[56] Kenhove, P. and Desrumaux, P. (1997), "The Relationship between Emotional States and Approach or Avoidance Response in a Retail Environment", The International Review of Retail, Distribution and Consumer Research, Vol. 7, pp. 351-68.

[57] Kim, H., and Lennon, S.J. (2010), "E-atmosphere, emotional, cognitive, and behavioral responses", Journal of Fashion Marketing and Management, Vol. 14, No. 3, pp. 412-428.

[58] Kotler, P. (1973), "Atmosphere as a marketing tool", Journal of Retailing, Vol. 49, No. 4, pp. 48-64.

[59] Krasonikolakis, I. G., Vrechopoulos, A. P. and Pouloudi, A. (2011), "Defining, Applying and Customizing Store Atmosphere in Virtual Reality Commerce: Back to Basics?" International Journal of EServices and Mobile Applications, Vol. 3, No. 2, pp. 59-72

[60] Kukreja, V.I. and Humphreys, D.W. (2014), “3D Virtual Store”, Google Patents, Vol. 14, No. 169

[61] Lam, S.Y. (2001), "The Effects of Store Environment on Shopping Behaviors: a Critical Review", in NA - Advances in Consumer Research, Vol. 28, eds. Mary C. Gilly and Joan Meyers-Levy, Valdosta, GA: Association for Consumer Research, pp. 190-197.

[62] Lazarus, R. S. (1991), Emotion and Adaptation, Oxford University Press, New York

[63] Lee, M., Kim, M., ad Peng, W. (2013), "Consumer reviews: Reviewer avatar facial expression and review valence", Internet Research, Vol. 23, pp. 116-132.

[64] Lin, I. (2004). "Evaluating a servicescape: the effect of cognition and emotion", Hospitality Management, Vol. 23, No. 2, pp. 163-178.

[65] Lin, J.C. and Liang, H. (2011), "The influence of service environments on customer emotions and service outcomes", Manage Service Quality, Vol. 21, No. 4, pp. 350-372.

[66] Li, J. (2004), The effects of store physical environment on perceived crowding and shopping behavior, Unpublished Doctoral Dissertation, Auburn University.

[67] Lutz, R. J. and Kakkar, P. (1975), "The Psychological Situation As a Determinant of Consumer Behavior", In NA - Advances in Consumer Research, 2, eds. Mary Jane Schlinger, Ann Abor, MI: Association for Consumer Research, pp. 439 -454.

[68] Lyer, E. S. (1989), "Unplanned purchasing: knowledge of shopping environment and time pressure" Journal of Retailing, Vol. 65, No. 1, pp. 40-57.
[69] MacKenzie, K., Buckby, S. and Irvine, H. (2013), "Business research in virtual worlds: possibilities and practicalities", Accounting, Auditing and Accountability Journal, Vol. 26, No. 3, pp. 352-373

[70] Machleit, K.A., Kellaris, J.J. and Eroglu, S.A. (1994), "Human versus Spatial Dimensions of Crowding Perceptions in Retail Environments: A Note on Their Measurement and Effect on Shopper Satisfaction", Marketing Letters, Vol. 5, No. 2, pp. 183-194.

[71] Machleit, K.A., Eroglu, S.A. and Mantel, P.S. (2000), "Perceived Retail Crowding and Shopping Satisfaction: What Modifies This Relationship?", Journal of Consumer Psychology, Vol. 9, No. 1, pp. 2942.

[72] Manganari, E.E., Siomkos, G.J., and Vrechopoulos, A.P. (2009), "Store atmosphere in web retailing", European Journal of Marketing, Vol. 43, No. 9/10, pp. 1140-1153.

[73] Manganari, E.E., Siomkos, G.J., Rigopoulou, I.D. and Vrechopoulos, A.P. (2011), "Virtual Store Layout effects on Consumer Behaviour", Internet Research, Vol. 21, No. 3, pp. 326-346.

[74] Mattila, A.S. and Wirtz, J, (2001), "Congruency of scent and music as a driver of in-store evaluations and behaviour", Journal of Retailing, Vol. 77, pp. 273-89.

[75] Mattila, A.S. and Wirtz, J. (2006), "Arousal expectations and service evaluations", International Journal of Service Industry Management, Vol. 17, No. 3, pp. 229-244.

[76] McGoldrick, P.J., and Collins, N. (2007), "Multichannel retailing: Profiling the multichannel Shopper", The International Review of Retail, Distribution and Consumer Research, Vol. 17 No. 2, pp. 139-58.

[77] Melancon, J.P. (2011), "Consumer profiles in reality vs fantasy-based virtual worlds: implications for brand entry", Journal of Research in Interactive Marketing, Vol. 5, No. 4, 298-312.

[78] Mehrabian, A. (1976), Public Spaces and Private Spaces: The Psychology of Work, Play and Living Environments. Basic Books Inc, New York

[79] Messinger, P.R., Eleni, S., Lyons, K., Bone, M., Niu, R., Smirnov, K. and Perelgut, S. (2008), "Virtual worlds - past, present, and future: New directions in social computing", Decision Support Systems, Vol. 47, No. 3, pp. 204-228

[80] Mehrabian, A., and Russell, J.A. (1974), An Approach to Environmental Psychology, MA: MIT Press, Cambridge

[81] Milliman, R.E. (1982), "Using background music to affect the behavior of supermarket shoppers", Journal of Marketing, Vol. 46, pp. 86-91.

[82] Milliman, R.E. (1986), "The influence of background music on the behavior of restaurant patrons", Journal of Consumer Research, Vol. 13, pp. 286-289.

[83] Morin, S., Dube, L. and Chebat, J. (2007), "The role of pleasant music in servicescapes: A test of the dual model of environmental perception", Journal of Retailing, Vol. 83, pp. 115-130.

[84] Nath, C.K. (2009), "Behaviour of Customers in Retail Store Environment- An Empirical Study", Journal of Management, pp. 63-74.

[85] Newman, A.J. (1997), Consumption and the inanimate environment: The airport setting (Doctoral dissertation). Manchester Metropolitan University, Manchester

[86] Newman, A.J. (2007), "Uncovering Dimensionality in the Servicescape: Towards Legibility", The Services Industries Journal, Vol. 27, No.1, pp. 15-28.

[87] Nood, D.D. and Attema, J. (2006), "Second Life, the Second Life of Virtual Reality", The Hague: EPN - Electronic Highway Platform.

[88] Price-Rankin, K. (2004). Online Atmospherics: An investigation of feeling and Internet purchase intention. Unpublished Doctoral Dissertation, The University of Tennessee, Knoxville.

[89] Quartier, K. (2011), Retail design: lighting as a design tool for the retail environment (Doctoral dissertation). Retrieved from ProQuest database.

[90] Reddy, N.R.V.R., Reddy, T.N., and Azeem, B.A. (2011), "Role of instore lighting in store satisfaction", International Journal of Business and Management Tomorrow, Vol. 1, No. 3, pp. 1-8.

[91] Reimer, A. and Kuehn, R. (2004), "The impact of servicescape on quality perception", European Journal of Marketing, Vol. 39, No. 7/8, pp. 785-808. 
[92] Richarme, M. (2007), "Consumer Decision-Making Models, Strategies, and Theories, Oh My! (Decision Analyst)", Available from the Data Analyst website: http://www.decisionanalyst.com/Downloads/ConsumerDecisionMaking. pdf (accessed on 27 December, 2014).

[93] Rosenbaum, M.S. (2005), "The symbolic servicescape: your kind is welcomed here", Journal of Consumer Behaviour, Vol. 4, No. 4, pp. 257-67.

[94] Rosenbaum, M.S., and Massiah, C. (2011), “An expanded servicescape perspective", Journal of Service Management, Vol. 22, No. 4, pp. 471490.

[95] Russell, J, (1980), "A Circumplex Model of Affect", Journal of Personality and Social Psychology, Vol. 39, No. 6, pp. 1161-1178.

[96] Russell, J. and Pratt, G. (1980), "A description of the affective quality attributed to environments", Journal of personality and social psychology, Vol. 38, pp. 311-346

[97] Ryu, K., and Jang, S. (2008), "DINESCAPE: A scale for customers' perception of dining environments", Journal of Foodservice Business Research, Vol. 11, No. 1, pp. 2-22.

[98] Schiffman, L.G., Kanuk, L.L. and Kumar, S.R. (2010), Consumer Behaivor (10 ${ }^{\text {th }}$ ed.). Dorling Kindersley Pvt. Ltd, UP, India

[99] Schlosser, A.E. (2003), "Experiencing products in a virtual world: The role of goals and imagery in influencing attitudes versus intentions", Journal of Consumer Research, Vol. 30, pp. 184-198

[100]Schlosser, A.E. (2006), "Learning Through Virtual Product Experience: The Role of Imagery on True and False Memories", Journal of Consumer Research, Vol. 33, pp. 377-383.

[101] Sherman, E., Mathur, A., and Smith, R.B. (1997), "Store environment and consumer purchase behavior: mediating role of consumer emotions", Psychology \& Marketing, Vol. 14, No. 4, pp. 361-378.

[102]Solomon, M., Bamossy, G., Askegaard, S. and Hogg, M.K. (2006), Consumer Behaviour: A European Perspective ( $3^{\text {rd }}$ ed.). Pearson Education Limited, New Jersey

[103] Spangenberg, E.R., Crowley, A.E. and Henderson, P.W. (1996), "Improving the store environment: Do olfactory cues affect evaluations and behaviors?", Journal of Marketing, Vol. 60, pp. 67-80.

[104] Spangenberg, E., Grohmann, B. and Sprott, D. (2005), "It's beginning to smell and (sound) a lot like Christmas: the interactive effects of ambient scent and music in a retail setting", Journal of Business Research, Vol. 58, pp. 1583-1589.

[105] Spangenberg, E., Sprott, D., Grohmann, B. and Tracy, D. (2006), "Gender-congruent ambient scent influences on approach and avoidance behaviors in a retail store", Journal of Business Research, Vol. 59, pp. 1281-1287.

[106]Spies, K., Hasse, F. and Loesch, K. (1997), "Store atmosphere, mood and purchasing behaviour", International Journal of Research in Marketing, Vol. 14, pp. 1-17.

[107] Statista (2015), "Retail sales revenue in the United Kingdom (UK) from 2012 to 2018 (in billion GBP)", Available from www.statista.com/statistics/285971/retail-sales-forecast-in-the-unitedkingdom-uk-2012-2017/ (accessed December, 2015)

[108]Stokols, D. (1972), On the distinction between density and crowding. Journal of American Institute of Planners, Vol. 38, pp. 72-83.

[109]Stokols, D. (1978), "Environmental Psychology", Annual Review of Psychology, Vol. 29, pp. 253-295

[110]Summers, T.A. and Hebert, P.R. (2001), "Shedding some light on store atmospherics: Influence of illumination on consumer behaviour", Journal of Business Research, Vol. 54, No. 2, pp. 145-150.

[111] Sweeney, J.C. and Wyber, F. (2002), "The role of cognitions and emotions in the music approach avoidance behaviour relationship", Journal of Service Marketing, Vol. 16, No.1, pp. 51-69.
[112]Tai, S.H.C. and Fung, A.M.C. (1997), "Application of an environmental psychology model to instore buying behaviour", The International Review of Retail, Distribution and Consumer Research, Vol. 7, No. 4, pp. 311-337.

[113]Turley, L.W. and Milliman, R.E. (2000), "Atmospheric effects on shopping behavior: a review of the experimental evidence", Journal of Business Research, Vol. 49, No. 2, pp. 193-211.

[114]Varley, R. and Rafiq, M. (2014), Principles of Retailing ( $2^{\text {nd }}$ ed.). Palgrave Macmillan, Basingstoke: England

[115]Vrechopoulos, A.P., O'Keefe, R.M., Doukidis, G.I. and Siomkos, G.J. (2004), "Virtual store layout: an experimental comparison in the context of grocery retail", Journal of Retailing, Vol. 80, pp. 13-22.

[116] Vrechopoulos, A., Apostolou, K., and Koutsiouris, V. (2009), "Virtual reality retailing on the web: emerging consumer behavioural patterns", The International Review of Retail, Distribution and Consumer Research, Vol. 19, No. 5, pp. 469-482.

[117]Wakefield, L.K. and Blodgett, J.G. (1994), "The importance of Servicescape in leisure Service Settings", The Journal of Services Marketing, Vol. 8, No. 3, pp. 66-76.

[118] Wakefield, K.L. and Blodgett, J.G. (1996), "The effect of servicescape on customers' behavioral intentions in leisure service settings", Journal of Services Marketing, Vol. 10, No. 6, pp. 45-61

[119] Wang, L.C., Baker, J., Wagner, J.A. and Wakefield, K. (2007), "Can a Retail Web Site be Social?", Journal of Marketing, Vol. 71, No. 3, pp. $143-157$

[120]Wang, Y.J., Minor, M.S. and Wei, J. (2011), “Aesthetics and the online shopping environment: Understanding consumer responses" Journal of Retailing, Vol. 87, No. 1, pp. 46-58

[121]Ward, P., Davies, B.J. and Kooijman, D. (2007), "Olfaction and the retail environment: examining the influence of ambient scent", Service Business, Vol. 1, pp. 295-316.

[122]Williams, R. and Dargel, M. (2004), "From servicescape to "cyberscape" Marketing Intelligence \& Planning, Vol. 22, No. 3, pp. 310-320.

[123]Wirtz, J., Mattila, A. and Tan, R. (2000), "The Moderating Role of Target-Arousal on the Impact of Affect on Satisfaction-An examination in the Context of Service Experiences", Journal of Retailing, Vol. 76, No. 3, pp. 347-365.

[124]Wu, C.S., Cheng, F.F., and Yen, D.C. (2008), “The atmospheric factors of online storefront environment design: An empirical experiment in Taiwan", Information \& Management, Vol. 45, pp. 493-498.

[125]Wysocki, B. (1979), "Sight, Smell, Sound: They're All Arms in Retailers's Arsenal”, The Wall Street Journal, Vol. 17, pp. 1-35.

[126] Wyld, D. C. (2010), "A Second Life for organizations?: managing in the new, virtual world", Management Research Review, Vol. 33, No. 6, pp. $529-562$.

[127] Yalch, R. and Spangenberg, E. (1988), An Environmental Psychological Study of Foreground and Background Music as Retail Atmospheric Factors. American Marketing Association, Chicago, IL, pp. 106-110.

[128] Yalch, R. and Spangenberg, E. (1990), "Effects of Store Music on Shopping Behavior", Journal of Consumer Marketing, Vol. 7, pp. 55-63.

[129] Yalch, R. and Spangenberg, E. (1993), "Using store music for retail zoning", In L. McAlister and M. Rothschild (Eds.), Advances in consumer research, (pp. 632-636). Provo, UT: Association for consumer research

[130] Yalch, R. and Spangenberg, E. (2000), "The Effect of Music in a Retail Setting on Real and Perceived Shopping Times", Journal of Business Research, Vol. 49, No. 2, pp. 139-147

[131]Young, W., Hwang, K., Mcdonald, S. and Oates, C.J. (2010), "Sustainable consumption: green consumer behaviour when purchasing products", Sustainable Development, Vol. 18 No. 1, pp. 20-31 